\title{
Corporate venture capital (CVC) Investments and Technological Performance: Geographic Diversity and the Interplay with Technology Alliances
}

Citation for published version (APA):

Belderbos, R., Jacob, J., \& Lokshin, B. (2018). Corporate venture capital (CVC) Investments and Technological Performance: Geographic Diversity and the Interplay with Technology Alliances. Journal of Business Venturing, 33(1), 20-34. https://doi.org/10.1016/j.jbusvent.2017.10.003

Document status and date:

Published: 01/01/2018

DOI:

10.1016/j.jbusvent.2017.10.003

Document Version:

Publisher's PDF, also known as Version of record

Document license:

Taverne

Please check the document version of this publication:

- A submitted manuscript is the version of the article upon submission and before peer-review. There can be important differences between the submitted version and the official published version of record.

People interested in the research are advised to contact the author for the final version of the publication, or visit the DOI to the publisher's website.

- The final author version and the galley proof are versions of the publication after peer review.

- The final published version features the final layout of the paper including the volume, issue and page numbers.

Link to publication

\footnotetext{
General rights rights.

- You may freely distribute the URL identifying the publication in the public portal. please follow below link for the End User Agreement:

www.umlib.nl/taverne-license

Take down policy

If you believe that this document breaches copyright please contact us at:

repository@maastrichtuniversity.nl

providing details and we will investigate your claim.
}

Copyright and moral rights for the publications made accessible in the public portal are retained by the authors and/or other copyright owners and it is a condition of accessing publications that users recognise and abide by the legal requirements associated with these

- Users may download and print one copy of any publication from the public portal for the purpose of private study or research.

- You may not further distribute the material or use it for any profit-making activity or commercial gain

If the publication is distributed under the terms of Article 25fa of the Dutch Copyright Act, indicated by the "Taverne" license above, 


\title{
Corporate venture capital (CVC) investments and technological performance: Geographic diversity and the interplay with technology alliances
}

\author{
René Belderbos ${ }^{\mathrm{a}, \mathrm{b}, \mathrm{d}, *}$, Jojo Jacob ${ }^{\mathrm{c}}$, Boris Lokshin ${ }^{\mathrm{d}}$ \\ a Department of Managerial Economics, Strategy and Innovation, KU Leuven, Naamsestraat 69, B-3000 Leuven, Belgium \\ ${ }^{\mathrm{b}}$ UNU MERIT, Maastricht University, Maastricht, The Netherlands \\ c Grenoble Ecole de Management, Department of Management, Technology and Strategy, 38000, Grenoble, France \\ d Department of Organization and Strategy, School of Business and Economics, Maastricht University, P.O. Box 616, 6200 MD Maastricht, The \\ Netherlands
}

\section{A R T I C L E I N F O}

\section{Keywords:}

CVC investments

Technology alliances

Technological performance

\begin{abstract}
A B S T R A C T
Firms are increasingly operating portfolios of geographically dispersed CVC investments for accessing a variety of location-specific knowledge, often alongside traditional external knowledgesourcing strategies such as technology alliances. We examine the conditions under which geographic diversity in corporate venture capital (CVC) investments has positive consequences for firms' technological performance in the context of simultaneously pursued technology alliance strategies. We find that geographic diversity in CVC portfolios enhances performance as long as firms avoid knowledge redundancy in knowledge-sourcing arising from geographic overlaps with technology alliances, and the managerial complexity, coordination costs, and resource constraints stemming from the simultaneous pursuit of diversity in both technology alliances and CVC investments. Our inferences draw on a panel data set on the patents, CVC investments, and technology alliances of 55 CVC-active firms in a variety of industries.
\end{abstract}

\section{Executive summary}

Driven by rapid technological change and a surge in new entrepreneurial ventures that pursue pioneering technologies, corporate venture capital (CVC) activities have experienced significant growth over the last quarter century. An increasing global dispersion of technology development activities and hubs of innovative ventures has also spurred an internationalization of CVC investments, with firms investing in promising ventures spread across locations each with their specialized expertise and knowhow. While prior research has established the importance of CVC activities as an external knowledge-sourcing strategy and has underscored that CVC activities can contribute to firms' innovation performance, we know little of the consequences of the increasing geographic spread of CVC investments.

In this study, we examine why and when (under what circumstances) geographic diversity of CVC investments influences the investing firms' technological performance, focusing on the interplay with firms' technology alliance strategies. Exploring new sources of knowledge outside traditional environments through CVC investments holds the promise of increasing the breadth of search, knowledge recombination, and cross-fertilization, thus improving the effectiveness of firms' technology development activities. However, CVC investments have developed alongside firms' existing technology alliance strategies, while firms did not

\footnotetext{
* Corresponding author at: Department of Managerial Economics, Strategy and Innovation, KU Leuven, Naamsestraat 69, B-3000 Leuven, Belgium.

E-mail address: rene.belderbos@kuleuven.be (R. Belderbos).
} 
necessarily have organizational structures in place for facilitating the coordination between these knowledge sourcing strategies sharing a range of features (in terms of resource commitment, flexibility, explorative focus, and duration). While previous studies juxtaposed the various sourcing strategies without considering the potential synergetic or detrimental effects that their joint engagement could bring about, our study develops and tests hypotheses on how the effects of the geographic diversity of CVC investments are moderated by the simultaneous pursuit of technology alliance strategies.

We expect that geographic diversity of CVC portfolios has a curvilinear relationship with technological performance. We then posit two ways in which the performance effects of CVC investments may be weakened if combined with a geographically diversified technology alliance portfolio. First, the managerial and coordination complexities of operating large, diverse portfolios of CVC investments and technology alliances simultaneously may have negative performance consequences. Second, the sourcing of redundant country-specific knowledge and expertise due to pursuing CVC investments and technology alliances with the same technology focus in the same locations will render knowledge sourcing portfolios of technology alliances and CVC investments less performant.

Testing our hypotheses on a panel data set comprising patents, CVC investments, and technology alliances of 55 CVC-active firms in a variety of industries, we find broad support for these hypotheses. Our study highlights that geographic diversity of international venturing matters, and demonstrates that the performance effects of CVC investments depend importantly on the broader portfolio of firms' knowledge-sourcing strategies. Our findings suggest that redundancy, managerial complexity, and resource constraints occurs across the portfolios of technology alliances and CVC investments and not only within the individual portfolios of either of these modes. Future research should explore to what extent sequential investment strategies or dedicated organizational coordination efforts could mitigate these factors and further enhance the effects of broader knowledge-sourcing portfolios.

\section{Introduction}

Driven by rapid technological change and a surge in new entrepreneurial ventures that pursue pioneering technologies, corporate venture capital (CVC) activities have experienced significant growth over the last quarter century (Keil, 2004; Dushnitsky, 2006; MacMillan et al., 2008; Dushnitsky and Lenox, 2005, 2006; Hill and Birkinshaw, 2015). An increasing global dispersion of technology development activities and hubs of innovative ventures (e.g. Chung and Yeaple, 2008; Lahiri, 2010; Belderbos et al., 2011) has also spurred an internationalization of CVC investments (Zahra and Hayton, 2008), with firms investing in promising ventures spread across locations each with their specialized expertise and knowhow ${ }^{1}$. While a growing stream of research has examined the importance of CVC activities as an external knowledge-sourcing strategy of established firms (e.g. Chesbrough and Tucci, 2004; Dushnitsky and Lenox, 2006; Henderson and Leleux, 2002; van de Vrande, 2013) and has underscored that CVC activities can contribute to firms' innovation performance (Dushnitsky and Lenox, 2005; Wadhwa and Kotha, 2006; Keil et al., 2008; van de Vrande et al., 2011), prior research has not paid substantive attention to the phenomenon of an increasing geographic spread of CVC investments ${ }^{2}$.

In this paper we contribute to the literature on CVC investments by examining why and when (under what circumstances) geographic diversity of CVC investments influences the investing firms' technological performance. We conceptualize CVC investments as knowledge-exploration instruments that can allow firms to access and recombine knowledge from distant technological and geographic contexts for improved technological performance (Rosenkopf and Almeida, 2003; Ahuja and Katila, 2004). In this conceptualization the potential benefits of the geographic diversity of knowledge search (the why question) derive from the notion that local firms and networks are embedded in unique technology search approaches and knowledge bases that are specific to local innovation systems (e.g. Phene et al., 2006). These local research traditions and scientific and technological strengths can spawn ventures that pursue unique approaches to technology development and that offer heterogeneous technological solutions (e.g. Furman et al., 2002). As a result, exploring new sources of knowledge outside traditional environments holds the promise of increasing the breadth of search, knowledge recombination, and cross-fertilization, thus improving the effectiveness of firms' technology development activities (Ahuja and Katila, 2004; Lahiri, 2010; Zhang et al., 2010; Belderbos et al., 2015a, 2015b).

We examine the question when geographic diversity matters by considering the interplay with a similar knowledge sourcing mode: technology alliances. CVC investments have developed alongside firms' existing technology alliance strategies (e.g. Keil et al., 2008; van de Vrande, 2013), but firms did not necessarily have organizational structures in place for facilitating the coordination between these strategies (e.g. Hill and Birkinshaw, 2015; Dushnitsky, 2011). Technology alliances are similar to CVC investments in terms of the level of resource commitment, flexibility, explorative focus, and duration (van de Vrande, 2013; Dushnitsky and Lavie, 2010) and have exhibited a strong tendency towards internationalization (e.g. Lavie and Miller, 2008). Recent research on the propensity to engage in alliances and CVC activities suggests a complex balance between the two strategies, resulting from internal resource constraints, potential redundancy, and reputational and visibility effects (Dushnitsky and Lavie, 2010). However, extant studies on knowledge-sourcing and firm performance, while recognizing that CVC investments are often used as technology-sourcing instruments in conjunction with other external knowledge-sourcing strategies, have juxtaposed the various sourcing strategies without considering the potential synergetic or detrimental effects that their joint engagement could bring about (e.g., Keil et al.,

\footnotetext{
${ }^{1}$ For instance, David Drummond, Google's senior VP of corporate development, was quoted in the Financial Times on the occasion of establishing a dedicated European CVC unit as saying, "As we look out around the world, we realise that the tech ecosystems are getting bigger and stronger. Every European capital I travel to I see these start up clusters. It's obvious that great companies will come out of these ecosystems”. 'Google to create European venture capital arm', Financial Times, July $10,2014$.

${ }^{2}$ A partial exception is Zahra and Hayton (2008), who found a positive association between cross-border CVC investments and other corporate venturing activities, and firms' subsequent revenue growth.
} 


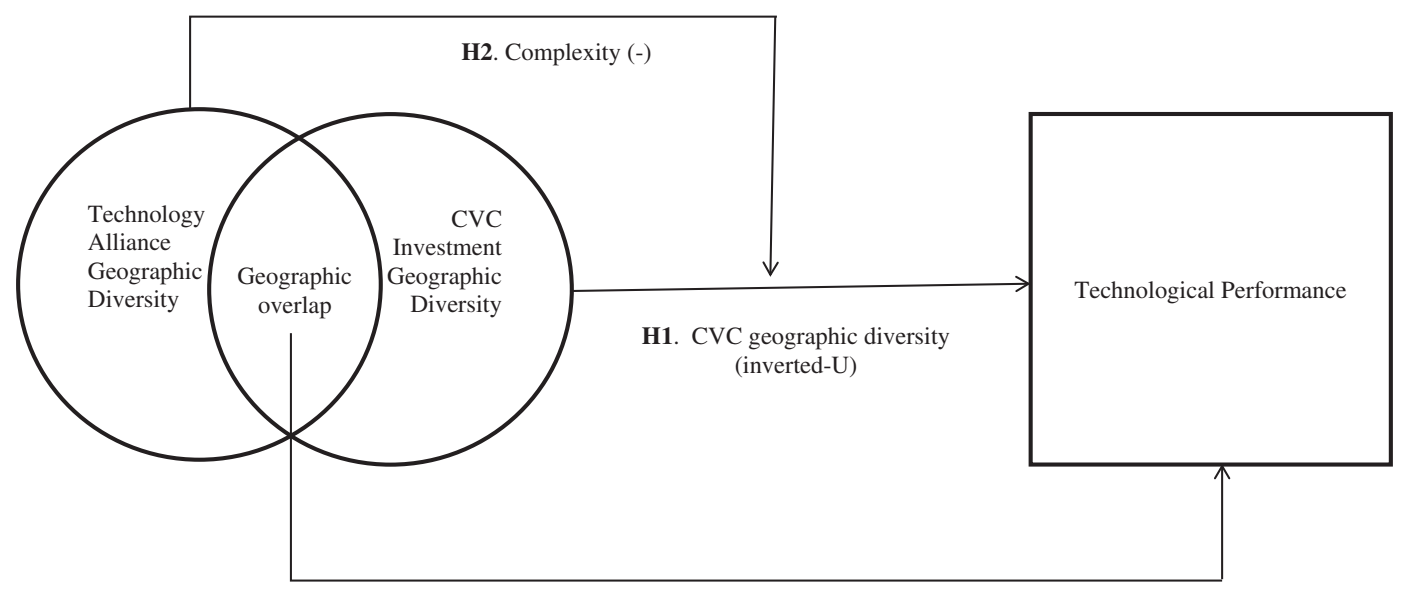

H3. Knowledge Redundancy (-)

Fig. 1. Conceptual Model: Interplay of CVC Geographic Diversity with Technology Alliance Geographic Diversity.

2008; Rothaermel and Hess, 2007; van de Vrande et al., 2011; Wadhwa and Kotha, 2006; Wadhwa et al., 2015). In this study, we take a portfolio perspective of CVC investments, following recent contributions to the CVC literature (Yang et al., 2014; Wadhwa et al., 2015; Matusik and Fitza, 2012), and extend this perspective to focus on firms' broader knowledge exploration portfolio consisting also of technology alliances.

We develop hypotheses anchored in the literature on search, learning and innovation, to contribute to the 'substantive' theory of CVC investments (e.g. Burgelman, 2011; Basu et al., 2011). Our aim is to better understand the consequences of the phenomenon of the internationalization of CVC investment portfolios in conjunction with firms' technology alliance activities, but not to develop a general theory of search and organizational learning through CVC investments. Our framework detailing the effect of the geographic diversity of CVC investments on technological performance taking into account the moderating effects of simultaneous technology alliance activities is illustrated in Fig. 1. Our baseline hypothesis is that the geographic diversity of CVC portfolios has a curvilinear relationship with technological performance. We then posit two ways in which the performance effects of CVC investments may be weakened if combined with a geographically diversified technology alliance portfolio. These relate to the managerial and coordination complexities of operating large, diverse portfolios of CVC investments and technology alliances simultaneously, and the potential sourcing of redundant country-specific knowledge and expertise due to pursuing CVC investments and technology alliances with the same technology focus in the same locations.

We test our hypotheses on a panel data set comprising patents, CVC investments, and technology alliances of 55 CVC-active firms in a variety of industries. Empirical results show that positive performance effects of CVC geographic diversity occur if firms do not simultaneously develop large and geographically overlapping technology alliance portfolios.

\section{Background and theory}

\subsection{Context-spanning knowledge search, learning and innovation}

The literature on search, learning and innovation highlights that distant search can increase firms' capacity for knowledge recombination and innovation by exposing them to a wide range of fresh ideas, insights, and practices (Levinthal and March, 1993; Katila and Ahuja, 2002; Ahuja and Katila, 2004; Davis and Eisenhardt, 2011; Rosenkopf and Nerkar, 2001; Lahiri, 2010; Leten et al., 2016). This view characterizes innovation processes as efforts to reconfigure knowledge situated in different domains into novel combinations (e.g. Fleming, 2001). Increasing the variety in firms' knowledge pool through distant search improves the extent to which knowledge combinations are possible, thereby augmenting innovation. Firms can enhance the variety of knowledge elements at their disposal by carrying out distant search in two dimensions: technological fields and geographic spaces (Rosenkopf and Almeida, 2003; Ahuja and Katila, 2004).

Theories of search and organizational learning also suggest tradeoffs associated with knowledge (sourcing) diversity. First, variety in search can entail significant costs. These costs stem from the complexity associated with a broad array of search and learning routines, in particular, when search involves different technology sourcing strategies and different contexts in which they are employed (North, 1990; Parkhe, 1993; Gulati and Singh, 1998; Hoffmann, 2007; Hoang and Rothaermel, 2005). While routines facilitate the process of learning and interaction with partners, and hence smoothen knowledge exchanges (Rosenkopf and Nerkar, 2001), developing them specific to particular contexts and modes is costly and can trigger competition for resources (Lavie et al., 2011). More generally, variety in knowledge sourcing strategies can spawn an array of different routines, which can exert a toll on the cognitive capacities of managers, increasing managerial complexities, and hence potentially weakening the recognition, integration and assimilation of knowledge and reducing the effectiveness of the knowledge-sourcing portfolio (e.g. Dess and Beard, 1984; Anderson, 1999; Ahuja and Katila, 2004). Second, the multiplicity of search activities increases the likelihood of generating 
redundant knowledge, which reduces the variety of the knowledge sourcing portfolio and further diminishes the efficiency of knowledge search (Rosenkopf and Almeida, 2003; Vassolo et al., 2004).

\subsection{CVC investments and innovation}

CVC investments have become a particularly popular mechanism for established companies to access newly created knowledge resources from entrepreneurial firms that possess unique technological capabilities and research approaches. Given the low resource commitments associated with CVC investments, firms are able to invest in novel initiatives undertaken by a wide range of start-up firms (Hurry et al., 1992; Dushnitsky and Lenox, 2006; Basu et al., 2011; Allen and Hevert, 2007). The literature on CVC investments has highlighted several opportunities for corporate investors to tap into new ventures' skills and expertise. Engagement in the due diligence process when assessing a venture's technological attractiveness, resources, and operations enables an incumbent firm to learn about the new start-up's emerging products and technologies even before committing any resource (Chesbrough, 2002; Dushnitsky and Lenox, 2005). Incumbents can also learn about ventures' key technologies and activities by taking board seats and by facilitating and establishing interchange activities. Corporate investors may even be able to benefit from investments in failed ventures if the technologies stay viable and feasible (Hoetker and Agarwal, 2004).

While CVC investments allow firms to keep abreast of developments in a variety of settings (Chesbrough, 2002; Dushnitsky and Lenox, 2005; Wadhwa and Kotha, 2006; Narayanan et al., 2009), ensuring efficient funneling of knowledge from the ventures requires the establishment of appropriate routines and procedures of interaction. These are likely to be different from their established search routines and organizational practices (Daft and Lengel, 1986; Dushnitsky and Lenox, 2006). Research on CVC investments as instruments of knowledge sourcing is fairly nascent and generally suggests a positive contribution to firms' innovation and financial performance (e.g. Dushnitsky and Lenox, 2005; Wadhwa and Kotha, 2006; Keil et al., 2008; van de Vrande et al., 2011; Zahra and Hayton, 2008).

In the hypothesis development below, we build on these ideas to contribute to the substantive theory of CVC investments and innovation. We focus on a dimension of distant search that has not received much attention in the literature: search in distant and divergent geographical contexts. We elaborate the circumstances under which a geographically diversified CVC investment portfolio is beneficial for innovation in the context of the simultaneous pursuit of international technology alliances, and examine the effects of complexity and knowledge redundancy.

\subsection{Hypotheses}

\subsubsection{Geographic diversity of CVC portfolios}

CVC investments may involve distant search for novel technologies and approaches if they target ventures in a variety of locations. Geographic context is an important source of variety in the search and technology development due to differences in institutional, regulatory, and market contexts and the varying strengths and roles of participants in local innovation systems. It is widely acknowledged that national culture, institutions and infrastructure exert a significant influence on the process of technology development, generating different trajectories across countries in the same technological domains (Ahuja and Katila, 2004; Porter, 1990). As they manifest local idiosyncrasies, country-specific knowledge elements tend to be sticky, with a large share of tacit, uncodified components (Jaffe et al., 1993; Saxenian, 1994). Thus even within finely defined technology domains, locational differences in innovation systems, context, and cognition lead to distinctive approaches to knowledge creation and to idiosyncratic research approaches (Phene et al., 2006).

Accessing such novel knowledge calls for linking up with local firms because idiosyncratic knowledge, which contains important tacit knowledge elements embodied in local organizations and their employees (Winter, 1987; Song et al., 2003), seldom spills over beyond the geographic location in which it is created (Jaffe et al., 1993; Saxenian, 1994; Verspagen and Schoenmakers, 2004). Access to these distinct knowledge elements from multiple countries through a geographically broad search process increases the choice set available to firms for problem solving and provides opportunities for recombination and cross-fertilization of knowledge (Almeida et al., 2002; Leiponen and Helfat, 2011). In turn, this may contribute to developing cutting-edge technologies and the creation of firstmover advantages (Kogut and Zander, 1992; Almeida et al., 2002). For established firms, exposure to diverse knowledge sets acts as a bulwark against falling into the danger of learning traps that may arise from their tendency to rely too much on familiar partners and environments (Ahuja and Lampert, 2001; Levinthal and March, 1993). New entrepreneurial ventures are likely to embody specific locational identities in search and tacit knowledge creation and provide an important means for accessing local idiosyncrasies in technology development. CVC investments thus expose incumbent firms to a valuable window on technology development associated with new research environments, innovation systems, and capabilities, allowing them to learn new skills and develop new technologies and applications (Zahra and Hayton, 2008; MacMillan et al., 2008).

While these arguments imply positive effects on innovation performance of a geographically diverse CVC investment portfolio, large extensions of portfolio diversity is costly and may generate reduced marginal benefits. Distant search among disparate partners requires more efforts in the recognition and integration of relevant knowledge (Fleming, 2001) because differences in the nationality and culture of partners can be a source of potential distrust and conflict (Hamel et al., 1989; Parkhe, 1993). Therefore, effective identification and assimilation of knowledge from partners requires relationship-specific investments (Dyer and Singh, 1998; Rosenkopf and Nerkar, 2001; Wadhwa et al., 2015). There may be limited scope economies if firms are unable to redeploy their expertise in identifying and integrating knowledge across ventures operating in different environments (Yang et al., 2014). Therefore, as firms' portfolio of CVC investments becomes more diverse, interactions with a more diverse set of partners with different 
characteristics is likely to raise the costs of absorbing diverse knowledge elements, which reduces the efficiency of the portfolio (Dess and Beard, 1984; Cohen and Levinthal, 1990; Anderson, 1999; Ahuja and Katila, 2004). Consequently, with increased geographic diversity of CVC investments, the ability to take optimal advantage of knowledge endowments in the portfolio may decrease.

It follows that a geographically diversified portfolio of CVC investments is likely to enable firms to increase their technological performance but that at higher levels of geographic diversity, the positive effects are likely to diminish while the costs of diversity increase. This suggests a nonlinear relationship between geographic diversity of CVC investments and technological performance, leading to the following baseline hypothesis:

Hypothesis 1. (geographic diversity): The geographic diversity of a firm's CVC investment portfolio has an inverted-U shaped relationship with the firm's technological performance.

\subsubsection{Complexity}

Firms often simultaneously employ international CVC investment and technology alliance strategies aimed at knowledge sourcing. Both CVC investments and technology alliances are mechanisms designed for exploration of knowledge with a focus on emerging technologies, and they both share characteristics such as termination flexibility and relatively low levels of commitment. At the same time, these two modes differ significantly in their approaches and practices with respect to inter-organizational relationships and knowledge exchanges. Whereas technology alliances involve mutual knowledge development and knowledge exchange and typically occur between established firms who share resources and costs, in CVC activities a target firm almost exclusively carries out the technology development processes, with the CVC investor providing mainly financial backing and, in some cases, strategic benefits such as offering solutions to short-term problems, allowing the venture to use its R \& D facilities, or introducing the venture to its network (Dushnitsky, 2006; Dushnitsky and Lavie, 2010).

Despite the benefits they can bring, geographically diversified portfolios that combine technology alliances with CVC investments may lead firms to face resource constraints and increased complexity of knowledge-sourcing that are likely to hamper effective learning. Complexity and increased demand on resources stem from heterogeneous knowledge-management practices associated with the two modes of knowledge-sourcing (Dyer and Singh, 1998; Zollo et al., 2002) as well as the characteristics of partners (Parkhe, 1993). Technology alliances and CVC investments entail the adoption of contrasting approaches to knowledge-sourcing. Knowledgeassimilation practices of CVC investors include taking board memberships in ventures and entrusting managers to work as liaisons between themselves and ventures (Keil, 2004; Dushnitsky and Lenox, 2006). Such linkages with new ventures are aimed at ensuring early identification of technological opportunities and providing timely assistance to the ventures. These practices diverge from those associated with technology alliances, where the focus is on explicit knowledge-sharing and gatekeeping (guarding outgoing knowledge flows) (e.g. Das and Teng, 2000).

The differences between CVC investments and technology alliances imply the need to deploy different routines for knowledge identification, transfer, and integration. Routines are considered integral to successful knowledge acquisition and integration because they reduce the transaction costs associated with the identification of resource owners, the sharing of tasks with partners, the monitoring of contracts, and the settling of disputes (Parkhe, 1993; Gulati and Singh, 1998). Since knowledge integration from CVC investments and technology alliances demand distinct routines, firms need to commit resources and managerial attention to develop routines specific to these two modes of knowledge sourcing. It is important to adopt the right set of routines, as routines that are appropriate for one mode may not be effective in another (Stettner and Lavie, 2014; Novick, 1988). Hence, learning in one mode of knowledge-sourcing cannot be easily leveraged in the other knowledge-sourcing mode. Firms with portfolios that combine the two strategies will therefore face reduced scope economies, while they forego the advantages of potential economies of scale arising from specializing in one mode of knowledge-sourcing. While this drives up the cost of knowledge sourcing, it may also diminish the beneficial effects of a geographically diversified portfolio. If firms spread their resources too thin across a variety of routines, this may result in a diminished ability to identify, acquire, and recombine relevant knowledge.

The geographic diversity of combined portfolios of technology alliances and CVC investments further exacerbates the complexity of knowledge-sourcing practices. Partners belonging to different national cultures follow different norms and customs in knowledge development and knowledge sharing (Kogut and Zander, 1992; Lavie and Miller, 2008). Understanding how to work effectively with alliance partners and CVC targets in different national contexts often necessitates developing specialized contextual knowledge and management routines and practices. The multiplicity of routines and the divergent knowledge-sharing decision rules and practices in communities with heterogeneous languages and norms (Matusik and Fitza, 2012) generate difficulties in coordinating, strategizing, and sharing experiences of the commonalities and differences between distant geographic locations and distinct partner types (Laursen and Salter, 2006; Foss et al., 2013; Gulati and Singh, 1998).

It follows that the combination of geographic diversity and sourcing-mode diversity and the resulting need for devising disparate routines and practices increases the cost and limits the benefits of managing a knowledge sourcing portfolio of geographically diverse technology alliances and CVC investments. The associated complexity exerts significant pressures on managers' scarce cognitive abilities and the firms' limited resources, thereby impairing the ability to observe, transfer, coordinate, integrate and recombine relevant external knowledge (Wadhwa et al., 2015; Phene et al., 2006). Hence, the inverted-U shaped relationship between CVC geographic diversity and technological performance is expected to show a flatter curvature and an earlier turn into a downward slope.

Hypothesis 2. (complexity). The geographic diversity of a firm's technology alliance portfolio negatively moderates the positive association between the geographic diversity of the firm's CVC investment portfolio and technological performance. 


\subsubsection{Knowledge redundancy}

While CVC investments and technology alliances may complement each other as technology-exploration strategies and hence each may lead to positive performance outcomes, a combined portfolio of diverse CVC investments and technology alliances can lead to sub-optimal outcomes if it generates redundant knowledge (Dushnitsky and Lavie, 2010). If these strategies lead to the creation of overlapping, redundant knowledge, the value of the portfolio is lower than the sum of the values of the individual investments (Vassolo et al., 2004; Mitchell, 1989; Dushnitsky and Lavie, 2010; Belderbos and Zou, 2009).

In the context of geographically dispersed external knowledge-sourcing strategies, redundant knowledge can result when a firm's knowledge-sourcing portfolio consists of technology alliances and CVC investments in an overlapping set of locations within the same technological domain. This may occur because alliances and CVC activities are typically managed by different parts of the organization, making coordination of these strategies difficult (Dushnitsky and Lavie, 2010; Dushnitsky, 2011). Pursuing CVC investments and alliances simultaneously in the same foreign country and in the same technology field may, therefore, result in the pursuit of similar tacit and specialized knowledge elements in the country. As a consequence, the contribution of a firm's CVC investments to knowledge variety diminishes when these are carried out in the same locations of the firm's technology alliance activities. This will reduce the general efficiency of the knowledge-sourcing portfolio as more resources and attention are devoted to the specific technologies and locations than is warranted by the novelty of knowledge and insights they can generate. Aside from the direct cost associated with the duplication of efforts to access localized idiosyncratic knowledge, accumulation of redundant knowledge elements may also put a further toll on a firm's cognitive resources, constraining managers' ability to identify and filter out useful information that can enrich the knowledge pool available to the firm.

These arguments suggest that simultaneous engagement in CVC investments and technology alliances in an overlapping set of countries within the same technology domain generates knowledge redundancies, weakens knowledge-recombination possibilities and the efficiency of the CVC investment portfolio, and therefore reduces technological performance:

Hypothesis 3. (knowledge redundancy): Geographic overlaps between a firm's portfolios of CVC investments and technology alliance activities within the same technology domain reduce the efficiency of a firm's knowledge sourcing portfolio and are therefore negatively associated with the firm's technological performance.

\section{Sample, data and methods}

\subsection{Sample and Data}

We collected panel data (1998-2007) on patents, financial information, CVC investments, and technology alliances of the five to ten top market leaders in the European Union across a broad spectrum of industries in manufacturing and selected technologyintensive services sectors (telecommunications and IT services). Among the 250 identified leading firms, 165 firms applied for at least one patent during the period and had financial information available. Among these 165 firms, only 55 firms engaged in CVC investments during the observation period, since CVC investments tend to be scarce in smaller firms (e.g., van de Vrande, 2013). As we are interested in the effects of CVC portfolio characteristics, our analysis focuses on these 55 firms, but we control for potential sample selection bias in the analyses.

The 55 firms are based in the US (15), Germany (6), France (4), the UK (7), and Japan (8) as well as in small and internationalized economies such as The Netherlands, Finland, Switzerland, and Sweden. The firms operate in a range of industries such as Food \& Tobacco (5), Paper and Printing (3), Chemicals and Pharma (10), Machinery (7), Electronics and Computer Equipment (12), Communications and Business Services (8), and Transportation Equipment and other industries (10).

Patent data were retrieved from the PATSTAT database and consist of patent applications with the European Patent Office. Given that the sample firms are major market players in European industries, they will have strong incentives to apply for protection of their inventions and technologies in Europe. In order to identify all patent applications by the firms, we used yearly information in consolidated accounts and information in annual reports on majority-owned affiliates. The 55 sample firms applied for 143,280 patents during the period 2001-2007 (the observation period on the dependent variable).

CVC information was retrieved from Thomson Financial's VentureXpert database, which combines information from industry associations (e.g., the European Venture Capital Association, the National Venture Capital Association) and the investment banking community. These data have been used in a range of prior studies (e.g., Gompers, 1995; Dushnitsky and Lenox, 2005; Dushnitsky and Lavie, 2010). We identified over a thousand unique CVC investments made by the sample firms for the period 1998-2007, where we focused only on the first investment of the firm in each venture. We retrieved data on the location of the ventures, the SIC codes, and the development stages of the ventures.

We used Thomson's SDC Platinum database as well as the MERIT-CATI database to gather information about the alliance activities of the sample firms. It is well known that these sources of alliance data overlap only modestly (Schilling, 2009). Therefore, combining complementary alliance information from the two databases strongly improves the accuracy of the alliance variables. We included only those alliances for which we had explicit information that technology development and technology-sharing were among the alliance objectives. Technology alliances on average make up about $15 \%$ of total alliances in the SDC database and $85 \%$ of the MERIT-CATI database. We identified some 1544 technology alliances undertaken by the sample firms during the observation period.

CVC investments and technology alliances are distinguished by SIC (SDC and VentureExpert) or technology field (CATI data). We map these SIC codes and technology fields into standard technology fields based on the concordance between World Intellectual Property Office (WIPO) technology classes and industries developed in Schmoch (2008). 
Our primary source of financial data was Compustat global and North America subsections. As Compustat has less than full coverage of European firms, we augmented these data with information retrieved from Worldscope and firms' annual reports. With regard to R \& D data, we additionally drew on the European R \& D Scoreboard, which ranks European and non-European firms by $R \& D$ expenditures. We used exchange rate information from IMF Financial Statistics to represent figures that were reported in domestic currencies in US dollars.

The data construction exercise provided us with a balanced panel data set of firms' technological performance, R \& D, and alliance and CVC activities for the years 1998-2007. Given that the technology alliance and CVC variables are measured in terms of portfolios over the past 3 years, the panel for estimation is restricted to 2001-2007 and includes 385 firm-year observations for the 55 firms ${ }^{3}$.

\subsection{Dependent variable - technological performance}

Following prior research on the technological performance implications of alliance and CVC activities (Dushnitsky and Lenox, 2005; Wadhwa and Kotha, 2006; Sampson, 2007; Keil et al., 2008; Wadhwa et al., 2015), we use the number of patents of the firm in a year as our technological performance measure. There are numerous advantages of using patent counts as measures of technological activities (Basberg, 1987; Griliches, 1990). Patent data are available in a consistent and longitudinal manner and provide 'objective' information in the sense that patents have been processed and validated by patent examiners based on novelty and utility of use. In line with previous studies, we used the patent application date as the first indication of a new capability or invention (e.g., Schmookler, 1966; Sampson, 2007). Our analysis controls for industry and firm-specific differences in the propensity to patent.

\subsection{Independent variables}

In constructing firms' CVC portfolios, we treat all CVC investments made by a focal firm within a three-year window as constituting its CVC portfolio. Since CVC investments have been found to affect innovativeness for about three to four years following the investment activity (Dushnitsky and Lenox, 2005; Wadhwa et al., 2015), we relate technological performance to CVC investments and their characteristics during the prior three years. In this respect, we follow the standard approach taken in the alliance literature (e.g. Gulati, 1995; Lavie and Miller, 2008). We construct firm portfolio variables through summation over individual CVC investments. We distinguish CVC investments by the geographic origin of the targets and compute the geographic diversity of the CVC investments, $D_{C V}$ as 1 over the Herfindahl concentration index of the CVC targets' countries of origin (e.g., Goerzen and Beamish, 2005). Formally this can be expressed as: $D_{C V}=1 / \Sigma_{j \in L(t)}\left[\Sigma_{t-3}{ }^{t-1} c v_{j, t} / C V_{t}\right]^{2}$ where $c v_{j, t}$ refers to the number of CVC investments of the focal firm in country $j$ at time $t, L$ is the total number of CVC target countries, and $C V$ is the total number of CVC investments. This diversity index, CVC geographic diversity, is the inverse of the Herfindahl index of concentration. The inverse of the Herfindahl index is also referred to as the 'number equivalent' of the Herfindahl index: it is the number of countries with CVC investments implied by the Herfindahl index if each country had an equal share of CVC investments. It varies between 1 (concentration of activities in one country) and the theoretical maximum equal to the total number of countries represented in the portfolio. It has the advantage that a unit change is more easily interpretable as the extension of geographic scope by one country with an equal share in CVC investments. We also include the square term since Hypothesis 1 predicts an inverted U-shaped relationship between the geographic diversity of CVC investments and technological performance.

Technology alliance geographic diversity is measured in the same manner as CVC geographic diversity. In order to test Hypothesis 2 , we include the interaction terms of technology alliance geographic diversity with the linear and square terms of CVC geographic diversity. Hypothesis 2 predicts a weakening of the inverted-U shaped relationship between technological performance and CVC geographic diversity at higher levels of technology alliance geographic diversity, implying both a flattening and a leftward shift of the curve.

Knowledge Redundancy (Hypothesis 3) is the degree to which the geographic pattern of technology alliances in a specific technology reduces the unique contribution of geographic diversity of the CVC portfolio of a firm in that technology. This is operationalized as the geographic overlap in CVC activities and technology alliances within the same technological field. We computed the extent of co-location between a firm's CVC investment targets and its technological alliance partners within the same technology fields using uncentered correlation (cf. Sampson, 2007; Ahuja and Katila, 2001). To construct this variable we first generate the distribution of each firm's CVC investment targets and alliance partners across countries and technologies, year by year. This distribution is captured by the vectors $C V=\left(C V^{11}, . ., C V^{k j}\right)$ and $T A=\left(T A^{11}, . ., T A^{k j}\right)$. The elements $C V^{k j}$ TA and $T A^{k j}$ of the vectors $C V T A$ and TA represent the number of CVC investment targets and alliance partners, respectively, from $\mathrm{t}-1$ through $\mathrm{t}-3$, of the focal firm $i$ that are located in country $k$ and technological class $j$. The extent of co-location between CVC and alliance activities is then: $R=C V_{i} T A_{i}^{\prime} / \sqrt{\left(C V_{i} C V_{i}^{\prime}\right)\left(T A_{i} T A_{i}^{\prime}\right)}$. This overlap or geographic knowledge redundancy measure ranges from 0 , signifying no redundancy, to 1, signifying complete redundancy, with the latter implying that all of the focal firm's alliance partners and CVC targets in each technology field are located in the same countries. Hypothesis 3 suggests a negative effect.

\subsection{Control variables}

We include the square term of geographic diversity of technology alliances to allow for diseconomies of scope in knowledge sourcing

\footnotetext{
${ }^{3}$ For CVC investments and technology alliances we extended the period to include 1995-1998 to allow testing for experience effects.
} 
through technology alliances. Since we are interested in testing for the influences of complexity due to simultaneous increases in CVC investments and alliances, it is important to control for a potentially declining marginal impact of increasing diversity in each of the technology sourcing modes.

We control for firms' host country alliance experience, gained through prior alliance activity in a country. The alliance experience variable is constructed as geographic overlap in past technology alliances and subsequent alliances, indicating the presence of relevant country experience. Using the proximity measure described above, we computed for each firm in our sample the extent of colocation between its technological alliance partners in years t- 4 through t- 6 and its alliances in years t- 1 through t-3. Similarly, the variable host country CVC experience is constructed as the geographic overlap between CVC investments in years t- 4 through t- 6 and CVC investments in years t-1 through $\mathrm{t}-3$.

We also control for technological relatedness between the ventures and the investing firm's existing knowledge base, to reflect that technology sourcing through CVCs may be more effective if relatedness ensures a stronger absorptive capacity (e.g. Zahra and Hayton, 2008). We determine whether the technology of the ventures is available in the technology portfolio of the investor and measure CVC technological relatedness as the share of CVC investments that overlap with the firm's existing technology (patent) portfolio. We also include the square term of this variable to allow for possible nonlinear effects of technological relatedness.

We include a set of controls to ensure that the variables related to geographic diversity indeed measure the impact of such diversity and do not reflect the influences of other factors such as technology diversity, other sourcing strategies, or the simple scale of technology-sourcing activities. We defined the variables technological diversity $(C V C)$ as the number of unique technology classes of a focal firm's CVC investment portfolio and technological diversity (alliances) as the number of unique technology classes of the firm's technology alliances, as a proportion of the total number of CVC targets and technology alliances, respectively. These variables control for the potential positive effect of a wider technological scope of technology-search strategies (e.g. Wadhwa et al., 2015). To help isolate the effects of geographic redundancy we also control for the overlap in technology fields covered by both CVC investments and technology alliances (technology overlap CVC and alliances) by calculating the uncentered correlation between technological classes of a focal firm's CVC investment portfolio and those of the technology alliances.

In order to control for other potential knowledge-sourcing and knowledge-integration strategies, we add the technological diversity of $M \& A s$ as the number of unique technology fields in which M \& A targets of the firms are active. We take a two-year portfolio of M \& As identified in SDC and the Zephyr database. M \& As are assumed to be technology-based or (partially) motivated by technology-sourcing if a target firm holds patents or if a target firm is active in technology alliances (e.g. Belderbos et al., 2011). We also control for the size of the technology-sourcing portfolios by including the overall number of CVC investments, technology alliances, and $\mathrm{M} \&$ As (portfolio size) in which a firm is engaged.

The models include variables controlling for characteristics of the CVC portfolio other than those related to geographic and technological diversity. CVC portfolio maturity may have a general effect on the knowledge sourcing potential of CVC investments. It is measured as the average stage of investments in a firm's CVC portfolio (e.g. Wadhwa et al., 2010), treating startup/seed, early stage, expansion, or late stage as an ordinal scale and calculating the average. Since CVC investments may differ in the extent to which they are focusing on knowledge sourcing and exploration on the one hand, or knowledge exploitation and commercialization on the other, the models include a control for potential exploitation motives. Since an exploitation focus is more likely to be prominent if CVC investments are targeting markets in which the firm has important sales and marketing operations, we take into account the extent to which CVC investments overlap with the distribution of the firm's global sales. We collected data on the regional sales profile of the investing firms and created the variable CVC market focus, measured as the share of global sales in regions in which the firm has CVC investments. As we have no prior on the functional form, we use a more general specification and also include the square term of the CVC market focus variable.

We further control for time-varying firm-level factors that are likely to affect technological performance: the value of $R \& D$ expenditures (in natural logarithm), firm size (the logarithm of firm sales), a firm's leverage, and slack. The latter, defined as the ratio of current assets to liabilities, is used to control for the availability of short-term liquidity. Inter-temporal trends in technological performance are controlled for by year dummies. Finally, unspecified unobserved heterogeneity in firm-level technological performance due to, for instance, general managerial capabilities or different propensities to patent, is controlled for by estimating pseudo-fixed effects models (see below).

\subsection{Methods}

The empirical models relate the technological performance measured by the number of patent applications of a firm in a given year to the firm's prior CVC and technology alliance activities. The dependent variable is a count variable with only non-negative integer values. In this case, nonlinear count data models, such as Negative Binomial or Poisson models, are preferred over standard linear regression models, as they explicitly take into account the non-negativity and discreteness of the dependent variable. We tested whether the assumption of the Poisson model that the variance of the dependent variable equals its mean holds (e.g., Cameron and Trivedi, 1998). The test rejected the null that the dispersion parameter alpha was equal to zero ( $\mathrm{p}$-value $=0.00$ ), and hence we employ the negative binomial regression models that allow for over-dispersion. We report the values of the over-dispersion parameter for our models in Table 2.

We estimate models using a pseudo-fixed effect estimator for count data due to Blundell et al. (1999). In this model, firm fixed effects are captured by the average value of the pre-sample observations of the dependent variable (the number of patents), which then enters the model as an additional explanatory variable. The pseudo fixed effects model controls for unobserved heterogeneity and has a number of additional advantages in the context of our research. Unlike random- or fixed-effects estimators, the pseudo fixed 
effects estimator does not rely on a strict exogeneity assumption regarding the explanatory variables (Blundell et al., 1999). This assumption would be violated if, for instance, an unobserved change in a firm's managerial abilities increases both its current knowledge-sourcing efforts and future patenting rates ${ }^{4}$. The pseudo fixed effects model also is more parsimonious compared with a fixed effects model given that it requires the estimation of only one coefficient, and, unlike negative binomial fixed or random effects estimators, allows for estimation of cluster-robust standard errors.

To address potential sample selection concerns due to our focus on 55 CVC-active firms from an initial larger set of firms, we implemented a two-stage approach that corrects for selection effects. We first estimated a first-stage probit model that explains firms' propensity to engage in CVC investments and subsequently include the Inverse Mill's ratio as an additional covariate in the technological performance models (e.g. Certo et al., 2016; Hass and Hansen, 2004). In the first-stage model we use the following instruments which prior research (e.g. Basu et al., 2011; Dushnitsky and Lenox, 2005) has identified as strong predictors of firms propensity to engage in CVC: firms' technological resources (the log of the number of patents in the last 5 years), technological diversity of alliances (the number of technological fields entered through alliances, scaled by the number of alliances), and technological diversity of $M \&$ As (the number of technological fields entered through $M$ \& As scaled by the number of M \& As). In addition, we include firm alliances (the count of the technological alliances in the past 3 years), firm acquisitions (the number of technological acquisitions in the past 2 years), geographic sales diversification (the Blau index of the distribution of firms' sales across regions), firm liquidity (the ratio of current assets to current liabilities), firm size (total revenues), firm age (the number of years since founding), firm R \& D stock (computed using the perpetual inventory method), the ratio of administrative and general expense to sales, and sets of industry, country, and year dummies. The first stage model is highly significant, with technological resources and the technological diversity of alliances as strong predictors of firms' decision to engage in CVC investments. Consistent with Basu et al. (2011) and Dushnitsky and Lenox (2005) we find that firm size, liquidity, and the number of prior alliances are also positively related to the propensity to engage in CVC investments.

\section{Empirical results}

Table 1 provides descriptive statistics. The sample firms on average apply for 372 patents per year, with a standard deviation of 440. The average geographic diversity of CVC investments is relatively small at 1.38 (standard deviation 0.56), while it is higher for technology alliances, at 2.49 (standard deviation 1.74). The geographic overlap at the technology level between CVC investments and technology alliance activities (knowledge redundancy) is relatively low: 0.05 on a $0-1$ scale, with a standard deviation of 0.09 . In addition, we can report that among firms engaging in alliances and CVC investments, the average technology alliance portfolio consists of 19 alliances, while the average CVC portfolio consists of 14 investments. The largest portfolios of alliances and CVC investments in our sample count 81 alliances and $100 \mathrm{CVC}$ investments, respectively. Correlations are moderate in most cases and do not raise multicollinearity concerns. Higher correlations are naturally observed between the pre-sample mean and technological performance, and between the linear and square terms of variables.

Table 2 reports the empirical results of the pseudo-fixed effects Negative Binomial models. Model I includes only the control variables and serves as a point of comparison for the other models in which we sequentially add the hypothesis-testing variables. The final model (V) includes all variables. Model I shows the expected positive and significant $(\beta=0.002, p=0.000)$ influence of the presample dependent variable (the pseudo fixed effect), in addition to a significantly positive effect of R\&D investments $(\beta=0.374, p=0.000)$. Firm size is also positively related to technological performance $(\beta=0.098, p=0.009)$ and leverage has a negative association $(\beta=-0.007, \mathrm{p}=0.000)$.

The size of the combined knowledge sourcing portfolio is insignificant but gains marginal significance with a negative sign in the more encompassing models. The technological diversity of technology alliances is positive and significant $(\beta=0.699, \mathrm{p}=0.003)$, but the variables controlling for the degree of technological diversity of the CVC investment portfolio and technological diversity of M \& As are not. The latter may be partially related to the post-acquisition integration difficulties of less related acquisitions (e.g., Hennart and Reddy, 1997; Ahuja and Katila, 2001; Belderbos et al., 2011). The variable measuring prior CVC country experience is significant and has a positive sign $(\beta=0.235, \mathrm{p}=0.043)$. The effect of geographic diversity of alliances is insignificant in model 1 but becomes positive and significant in the more encompassing models, in line with prior findings in the literature (e.g., Lavie and Miller, 2008).

Technological relatedness between the CVC investments and firms' existing technological expertise appears to have a weak inverted-U shaped relationship with technological performance in model 1, but this effect disappears in the more encompassing models. Technology overlap in CVC and technology alliance portfolios is significant (at the $10 \%$ level) and negatively related to technological performance $(\beta=-0.407, p=0.064)$, in line with the general argument on knowledge redundancy if firms pursue overlapping knowledge sourcing strategies simultaneously.

The maturity of the CVC portfolio is also negatively associated with technological performance $(\beta=-0.109, \mathrm{p}=0.006)$.CVC market focus has a weakly significant $\left(\beta_{1}=0.763, \mathrm{p}=0.090 ; \beta_{2}=-1.196, \mathrm{p}=0.018\right)$ inverted-U shaped relationship with technological performance. The estimated coefficients suggest an initial positive effect of market focus, with the marginal effect turning negative at around the mean value (0.3). This may indicate that some familiarity with the locations in which CVC investments take place is positive for knowledge sourcing. On the other hand, geographic configurations of CVC investments that are closely aligned with existing sales locations are likely to reflect knowledge exploitation strategies, providing limited learning potential for CVC

\footnotetext{
${ }^{4}$ Technically speaking, the pseudo fixed effects estimator remains consistent, as it requires explanatory variables only to be pre-determined, not strictly exogenous.
} 
Table 1

Descriptive statistics and pairwise correlations for sample firms.

\begin{tabular}{|c|c|c|c|c|c|c|c|c|c|c|c|c|c|c|c|}
\hline & Variables & Mean & SD & Min & Max & 1 & 2 & 3 & 4 & 5 & 6 & 7 & 8 & 9 & 10 \\
\hline 1 & Technological performance & 372.16 & 440.92 & 0.00 & 2305.00 & & & & & & & & & & \\
\hline 2 & Pre-sample mean & 281.87 & 294.15 & 0.60 & 1480.00 & 0.89 & & & & & & & & & \\
\hline 3 & Firm size & 16.67 & 2.57 & 0.01 & 19.30 & 0.27 & 0.31 & & & & & & & & \\
\hline 4 & Leverage & 32.8 & 23.52 & 0.00 & 112.57 & -0.21 & -0.17 & 0.22 & & & & & & & \\
\hline 5 & Firm liquidity & 1.61 & 2.6 & 0.00 & 50.00 & -0.02 & -0.04 & -0.47 & -0.19 & & & & & & \\
\hline 6 & $\mathrm{R} \& \mathrm{D}$ & 6.83 & 1.74 & 0.43 & 9.41 & 0.49 & 0.55 & 0.51 & -0.10 & -0.07 & & & & & \\
\hline 7 & Portfolio size & 2.54 & 1.26 & 0.00 & 4.88 & 0.40 & 0.43 & 0.23 & -0.21 & 0.01 & 0.69 & & & & \\
\hline 8 & CVC tech relatedness & 0.09 & 0.16 & 0.00 & 0.69 & 0.04 & 0.05 & 0.03 & -0.23 & -0.01 & 0.21 & 0.45 & & & \\
\hline 9 & CVC tech relatedness squared & 0.03 & 0.08 & 0.00 & 0.48 & -0.02 & -0.01 & 0.02 & -0.23 & 0.00 & 0.17 & 0.38 & 0.96 & & \\
\hline 10 & CVC market focus & 0.45 & 0.41 & 0.00 & 1.00 & 0.14 & 0.16 & -0.02 & -0.16 & 0.06 & 0.31 & 0.61 & 0.45 & 0.37 & \\
\hline 11 & CVC market focus squared & 0.36 & 0.38 & 0.00 & 1.00 & 0.11 & 0.13 & -0.02 & -0.14 & 0.07 & 0.31 & 0.62 & 0.48 & 0.40 & 0.98 \\
\hline 12 & Tech diversity CVC & 0.09 & 0.17 & 0.00 & 0.80 & 0.22 & 0.18 & -0.01 & -0.07 & 0.08 & 0.10 & 0.36 & 0.25 & 0.17 & 0.41 \\
\hline 13 & Tech diversity alliances & 0.18 & 0.20 & 0.00 & 0.86 & 0.34 & 0.37 & 0.22 & -0.05 & -0.05 & 0.41 & 0.47 & 0.02 & 0.01 & 0.23 \\
\hline 14 & Tech diversity $\mathrm{M} \& \mathrm{~A}$ & 0.07 & 0.18 & 0.00 & 0.80 & 0.33 & 0.31 & 0.13 & -0.06 & -0.03 & 0.21 & 0.31 & 0.20 & 0.15 & 0.22 \\
\hline 15 & Host country alliance experience & 0.58 & 0.40 & 0.00 & 1.00 & 0.41 & 0.47 & 0.38 & -0.17 & -0.06 & 0.74 & 0.78 & 0.26 & 0.22 & 0.34 \\
\hline 16 & Host country CVC experience & 0.41 & 0.47 & 0.00 & 1.00 & 0.14 & 0.17 & -0.05 & -0.07 & 0.07 & 0.31 & 0.56 & 0.29 & 0.24 & 0.66 \\
\hline 17 & Tech overlap alliances and CVC & 0.10 & 0.22 & 0.00 & 0.97 & 0.21 & 0.19 & 0.03 & -0.16 & -0.02 & 0.23 & 0.47 & 0.29 & 0.24 & 0.45 \\
\hline 18 & CVC portfolio maturity & 1.59 & 1.25 & 0.00 & 4.00 & -0.00 & 0.03 & -0.00 & -0.03 & -0.02 & 0.06 & 0.03 & -0.06 & -0.08 & 0.10 \\
\hline 19 & Geo diversity alliances & 2.49 & 1.74 & 0.00 & 9.66 & 0.35 & 0.34 & 0.23 & 0.01 & -0.03 & 0.49 & 0.63 & 0.11 & 0.06 & 0.30 \\
\hline 20 & Geo diversity alliances squared & 9.22 & 12.51 & 0.00 & 93.32 & 0.24 & 0.21 & 0.15 & 0.06 & -0.03 & 0.28 & 0.43 & 0.07 & 0.03 & 0.25 \\
\hline 21 & Geo diversity CVC & 1.38 & 0.56 & 0.00 & 4.50 & 0.18 & 0.17 & -0.01 & -0.16 & 0.07 & 0.18 & 0.48 & 0.39 & 0.30 & 0.65 \\
\hline 22 & Geo diversity CVC squared & 2.21 & 2.20 & 0.00 & 20.25 & 0.13 & 0.10 & -0.03 & -0.11 & 0.07 & 0.06 & 0.29 & 0.31 & 0.25 & 0.46 \\
\hline \multirow[t]{2}{*}{23} & Knowledge redundancy & 0.05 & 0.09 & 0.00 & 0.50 & 0.02 & 0.02 & -0.01 & -0.25 & 0.08 & 0.24 & 0.45 & 0.44 & 0.40 & 0.43 \\
\hline & Variables & 11 & 12 & & 13 & 14 & 15 & 16 & 17 & 18 & 19 & & 20 & 21 & 22 \\
\hline 12 & Tech diversity CVC & 0.39 & & & & & & & & & & & & & \\
\hline 13 & Tech diversity alliances & 0.22 & 0.1 & & & & & & & & & & & & \\
\hline 14 & Tech diversity $\mathrm{M} \& \mathrm{~A}$ & 0.21 & 0.0 & & 0.15 & & & & & & & & & & \\
\hline 15 & Host country alliance experience & 0.35 & 0.1 & & 0.52 & 0.25 & & & & & & & & & \\
\hline 16 & Host country CVC experience & 0.66 & 0.3 & & 0.28 & 0.13 & 0.36 & & & & & & & & \\
\hline 17 & Tech overlap alliances and CVC & 0.48 & 0.5 & & 0.26 & 0.14 & 0.33 & 0.38 & & & & & & & \\
\hline 18 & CVC portfolio maturity & 0.00 & 0.0 & & 0.11 & 0.03 & 0.03 & 0.29 & -0.12 & & & & & & \\
\hline 19 & Geo diversity alliances & 0.32 & 0.2 & & 0.42 & 0.22 & 0.50 & 0.29 & 0.20 & -0.06 & & & & & \\
\hline 20 & Geo diversity alliances squared & 0.27 & 0.1 & & 0.27 & 0.18 & 0.29 & 0.20 & 0.12 & -0.06 & 0. & 92 & & & \\
\hline 21 & Geo diversity CVC & 0.62 & 0.4 & & 0.10 & 0.12 & 0.20 & 0.52 & 0.31 & 0.29 & 0. & 15 & 0.14 & & \\
\hline 22 & Geo diversity CVC squared & 0.45 & 0.4 & & 0.02 & 0.05 & 0.07 & 0.32 & 0.20 & 0.09 & 0. & 05 & 0.07 & 0.89 & \\
\hline 23 & Knowledge redundancy & 0.44 & 0.1 & & 0.08 & 0.18 & 0.31 & 0.31 & 0.32 & 0.12 & 0. & 17 & 0.07 & 0.34 & 0.18 \\
\hline
\end{tabular}

Note. Correlations based on 385 observations for 55 firms. Correlations greater than $|0.10|$ are statistically significant at an alpha level of 0.05 , and correlations greater than $|0.13|$ are statistically significant at the $10 \%$ level. Means and standard deviations of the alliance and CVC related variables are for firms that have positive values. $\mathrm{R} \& \mathrm{D}$, firm size and portfolio size are taken in natural logarithm-see the main text for the definition of variables.

investments and leading to reduced effects on technological performance. The market focus effects are, however, not robust in the broader hypotheses testing models.

When geographic diversity of CVC investments and its square term are added (model II) they suggest an inverted U-shaped relationship between CVC geographic diversity and technological performance $\left(\beta_{1}=0.435, \mathrm{p}=0.005\right),\left(\beta_{2}=-0.095, \mathrm{p}=0.012\right)$, in support of Hypothesis 1 . Model III reveals a significantly negative coefficient for the interaction term between the geographic diversity of technology alliances $\left(\beta_{1}=-0.228, \mathrm{p}=0.000\right)$ and the linear term of geographic diversity of CVC investments, and a significantly positive coefficient for the interaction with the square term $\left(\beta_{2}=-0.042, p=0.020\right)$. The resulting consequences for the relationship between the geographic diversity of CVC investments and predicted technological performance are illustrated in Fig. 2. The graphs are drawn when the geographic diversity of technology alliances is taken, respectively, at the mean minus one standard deviation ('low level' of diversity) and at the mean plus one standard deviation ('high level' of diversity), keeping the values of all other variables at their sample mean. While geographic diversity of CVC investments can have substantial performance effects until the optimal level of diversity, at higher geographic diversity of technology alliances, the curve is flatter, the maximum performance effect is smaller, and this maximum is reached at a lower level of CVC geographic diversity. These patterns are consistent with Hypothesis $2^{5}$.

The knowledge redundancy variable (geographic overlap between CVC investments and technology alliances), added to model IV,

\footnotetext{
${ }^{5}$ We confirmed that that the expression $\left(\beta_{1} \beta_{4}-\beta_{2} \beta_{3}\right) / 2\left(\beta_{2}+\beta_{4} Z\right)^{2}$, with $\beta_{1}$ the coefficient on the linear term, $\beta_{2}$ on the square term, $\beta_{3}$ on the linear interaction and $\beta_{4}$ on the squared interaction, respectively, is negative, in support of a shift of the curve to the left (Haans et al., 2016) - although the Wald test narrowly rejected significance of this expression. The sign and significance of $\beta_{4}$ confirms a flattening of the curve. If an additional interaction term between the square terms of the geographic diversity of CVC investments and technology alliances is included, its coefficient is insignificant, while the empirical results do not change materially.
} 
Table 2

The effects of CVC geographic diversity on technological performance.

\begin{tabular}{|c|c|c|c|c|}
\hline & Model I & Model II & Model III & Model IV \\
\hline \multirow[t]{2}{*}{ Pre-sample mean } & $0.002^{* * * * *}$ & $0.002^{* * * *}$ & $0.002^{* * * *}$ & $0.002^{\text {***** }}$ \\
\hline & $(0.000)$ & $(0.000)$ & $(0.000)$ & $(0.000)$ \\
\hline \multirow[t]{2}{*}{ Inverse Mill's ratio } & -0.034 & -0.082 & -0.153 & -0.174 \\
\hline & $(0.123)$ & $(0.123)$ & $(0.125)$ & $(0.124)$ \\
\hline \multirow[t]{2}{*}{ Firm size } & $0.098^{* * * *}$ & $0.093^{* *}$ & $0.101^{* * * * *}$ & 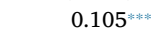 \\
\hline & $(0.038)$ & $(0.039)$ & $(0.038)$ & $(0.037)$ \\
\hline \multirow[t]{2}{*}{ Leverage } & $-0.007^{* * * *}$ & $-0.007^{* * * *}$ & $-0.006^{* * *}$ & $-0.007^{\text {**** }}$ \\
\hline & $(0.002)$ & $(0.002)$ & $(0.002)$ & $(0.002)$ \\
\hline \multirow[t]{2}{*}{ Firm liquidity } & -0.045 & -0.049 & -0.053 & $-0.053^{*}$ \\
\hline & $(0.033)$ & $(0.033)$ & $(0.031)$ & $(0.030)$ \\
\hline \multirow[t]{2}{*}{$\mathrm{R} \& \mathrm{D}$} & $0.374^{\text {**** }}$ & $0.379^{* * * *}$ & $0.345^{* * *}$ & $0.342^{* * *}$ \\
\hline & $(0.056)$ & $(0.056)$ & $(0.054)$ & $(0.053)$ \\
\hline \multirow[t]{2}{*}{ Portfolio size } & 0.002 & -0.074 & $-0.135^{*}$ & $-0.130^{*}$ \\
\hline & $(0.076)$ & $(0.076)$ & (0.077) & $(0.077)$ \\
\hline \multirow[t]{2}{*}{ CVC tech relatedness } & 1.121 & 0.770 & 0.867 & 0.979 \\
\hline & $(0.819)$ & $(0.818)$ & $(0.780)$ & $(0.791)$ \\
\hline \multirow[t]{2}{*}{ CVC tech relatedness squared } & $-2.863^{*}$ & -2.225 & -2.336 & -2.295 \\
\hline & (1.549) & (1.550) & (1.510) & (1.587) \\
\hline \multirow[t]{2}{*}{ CVC market focus } & $0.763^{*}$ & 0.583 & 0.333 & 0.288 \\
\hline & $(0.450)$ & $(0.461)$ & $(0.436)$ & $(0.428)$ \\
\hline \multirow[t]{2}{*}{ CVC market focus squared } & $-1.196^{* *}$ & $-1.190^{* *}$ & $-0.820^{*}$ & -0.736 \\
\hline & $(0.506)$ & $(0.515)$ & $(0.493)$ & $(0.484)$ \\
\hline \multirow[t]{2}{*}{ Tech diversity CVC } & 0.253 & 0.195 & 0.363 & 0.370 \\
\hline & $(0.249)$ & $(0.264)$ & $(0.252)$ & $(0.251)$ \\
\hline \multirow[t]{2}{*}{ Tech diversity alliances } & $0.699^{* * *}$ & $0.788^{* * * *}$ & $0.562^{* *}$ & $0.515^{* *}$ \\
\hline & $(0.232)$ & $(0.229)$ & $(0.230)$ & $(0.229)$ \\
\hline \multirow[t]{2}{*}{ Tech diversity M \& A } & -0.048 & 0.010 & -0.042 & -0.021 \\
\hline & $(0.173)$ & $(0.179)$ & $(0.173)$ & (0.169) \\
\hline \multirow[t]{2}{*}{ Host country alliance experience } & -0.067 & -0.019 & 0.088 & 0.090 \\
\hline & $(0.185)$ & $(0.176)$ & $(0.173)$ & $(0.171)$ \\
\hline \multirow[t]{2}{*}{ Host country CVC experience } & $0.235^{* *}$ & $0.220^{*}$ & $0.295^{* * * *}$ & $0.274^{* *}$ \\
\hline & $(0.116)$ & $(0.114)$ & $(0.108)$ & $(0.107)$ \\
\hline \multirow[t]{2}{*}{ Tech overlap alliances and CVC } & -0.407 & $-0.467 * *$ & $-0.497^{* *}$ & $-0.460^{* *}$ \\
\hline & $(0.220)$ & $(0.229)$ & $(0.218)$ & $(0.218)$ \\
\hline \multirow[t]{2}{*}{ CVC portfolio maturity } & $-0.109^{* * *}$ & $-0.175^{* * * *}$ & $-0.184^{* * * *}$ & $-0.172^{* * *}$ \\
\hline & $(0.040)$ & $(0.046)$ & $(0.050)$ & $(0.051)$ \\
\hline \multirow[t]{2}{*}{ Geo diversity alliances } & 0.010 & 0.045 & $0.180^{* *}$ & $0.201^{* *}$ \\
\hline & $(0.086)$ & $(0.087)$ & $(0.081)$ & $(0.083)$ \\
\hline \multirow[t]{2}{*}{ Geo diversity alliances squared } & 0.005 & 0.003 & 0.007 & 0.004 \\
\hline & $(0.010)$ & $(0.010)$ & $(0.008)$ & $(0.008)$ \\
\hline Geo diversity CVC & & $0.435^{* * * * *}$ & $1.014^{* * * *}$ & $1.021^{\text {***** }}$ \\
\hline & & $(0.154)$ & $(0.189)$ & $(0.188)$ \\
\hline Geo diversity CVC squared & & $-0.095^{* *}$ & $-0.218^{* * *}$ & $-0.224^{* * *}$ \\
\hline & & $(0.038)$ & $(0.045)$ & $(0.044)$ \\
\hline Geo diversity CVC $\times$ Geo diversity alliances & & & $-0.228^{* * * *}$ & $-0.223^{\text {***** }}$ \\
\hline & & & $(0.049)$ & $(0.049)$ \\
\hline Geo diversity CVC squared $\times$ Geo diversity alliances & & & $0.043^{* *}$ & $0.044^{* *}$ \\
\hline & & & $(0.019)$ & $(0.019)$ \\
\hline Knowledge redundancy & & & & $\begin{array}{r}-0.895 \\
(0.468)\end{array}$ \\
\hline Log-likelihood & -2372.8 & -2369.2 & -2358.6 & -2357.2 \\
\hline $\mathrm{R}^{2}$ & 0.10 & 0.10 & 0.11 & 0.11 \\
\hline Wald test of model significance & $1025.4^{* * * *}$ & $1079.9^{* * * * *}$ & $1227.7^{* * * *}$ & $1267.1^{\text {**** }}$ \\
\hline Over-dispersion parameter & $0.498^{* * * *}$ & $0.490^{* * * *}$ & $0.464^{* * * *}$ & $0.461^{\text {**** }}$ \\
\hline
\end{tabular}

Notes: Results of pseudo fixed effects negative binomial models with robust standard errors. The models are estimated on 385 observations for 55 firms. Constant and 6 time dummies included.

$$
\begin{aligned}
& { }^{*} \mathrm{p}<0.1 . \\
& { }^{* *} \mathrm{p}<0.05 . \\
& { }^{* * *} \mathrm{p}<0.01 .
\end{aligned}
$$

has a negative and significant (albeit at the $10 \%$ level) coefficient $(\beta=-0.895, \mathrm{p}=0.056)$, in support of Hypothesis 3. Calculations show that a standard deviation increase in redundancy from its mean value could reduce technological performance by $10 \%$.

\subsection{Supplementary analysis}

While our analysis controls for technological diversity of the knowledge sourcing strategies and the overlap in technologies 


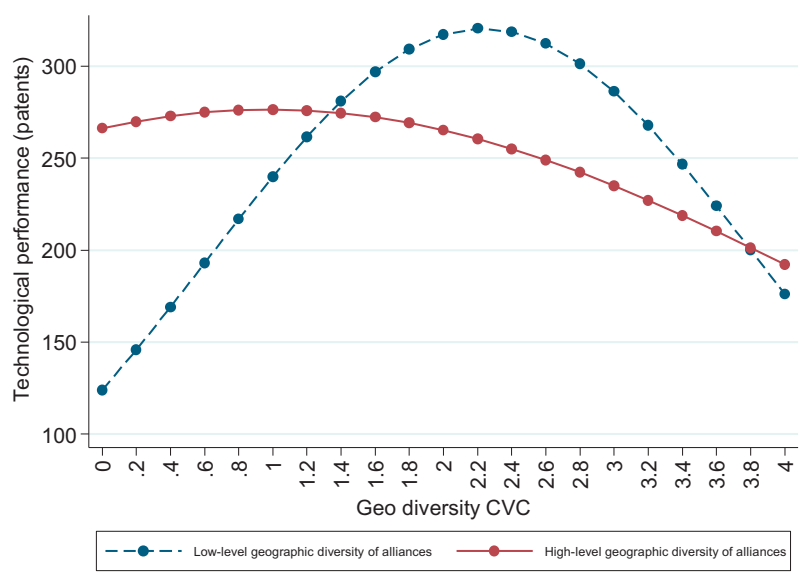

Fig. 2. Predicted technological performance as a function of the geographic diversity of CVC investments and the geographic diversity of alliances (complexity). Notes: graphs are drawn with all other variables taken at the sample mean. Low-level geographic diversity is diversity at the mean minus one standard deviation and high-level is at the mean plus one standard deviation.

pursued, we further investigated potential interrelationships between the geographic and technological dimensions of search. One possibility is that there is a tradeoff between the two dimensions, as firms with a narrow technology search strategy can more effectively pursue geographic diversity. To examine this question empirically, we included an interaction effect between CVC technology diversity and CVC geographic diversity. While the interaction term carried the expected negative sign, it was not significant in the model estimations.

We estimated models with an alternative dependent variable. Instead of patent counts we used the number of forward citations received by the firm's patents in a four-year window subsequent to the patent application. While differences in forward citations are likely to reflect differences in the value of patents, Kim (2015) points out that forward citations not only pick up technological contribution and knowledge creation, but also reflect differences in appropriation and value-capture strategies - which are less directly related to our theory and tests. Estimation of models with forward citations as the dependent variable nevertheless produced highly comparable results.

We examined potential endogeneity of our core explanatory variables by relaxing the assumption that the focal variables are predetermined. We estimated GMM models in which we instrumented geographic diversity in its linear form, complexity, and knowledge redundancy with their lagged values (measured in the period t-4 through t-6). The GMM specifications produced similar results and the Hansen test did not reject the exogeneity of instruments ${ }^{6}$. These indicative results, together with our use of pseudo-fixed effects models to control for unobserved firm heterogeneity, the control for selection effects, the elaborate set of time-variant firm variables, the adoption of lagged focal variables, and the focus on moderating effects and specific characteristics of CVC investments rather than on technology-sourcing strategies per se, mitigate concerns over potential endogeneity bias in our estimates due to selection, unobserved heterogeneity or reverse causality.

\section{Discussion and conclusion}

In today's increasingly globalized world, established firms are adopting a globally dispersed knowledge-sourcing strategy through multiple modes, with CVC investments becoming a major recent addition to traditional external knowledge-sourcing strategies such as technology alliances. This raises questions concerning the benefits of pursuing a geographically diverse CVC-investment strategy but also about the tensions arising from the parallel pursuit of a geographically diverse technology alliance strategy. Firms may yet have to recognize these tensions properly given their more recent experience with CVC strategies.

The current study addresses these concerns by examining why and when geographic diversity in CVC investments has (positive) consequences for firms' technological performance in the context of simultaneously pursued technology alliance strategies. Anchoring our research in the literature on search, learning and innovation, we proposed that geographic diversity in CVC portfolios can enhance technological performance by allowing access to a broad array of firms and their networks that are embedded in local systems of innovation, each with their distinct knowledge bases and approaches and traditions to knowledge development. By exploring new sources of knowledge in multiple locations, firms increase the breadth of knowledge elements available for recombination and cross-fertilization, thereby enhancing the effectiveness of their knowledge sourcing portfolios. As firms' portfolios of CVC investments becomes more diverse, interactions with a more diverse set of partners in various countries is likely to increase the difficulties and costs of absorbing and recombining diverse knowledge elements, such that an inverted-U shaped relationship between the geographic diversity of CVC investments and technological performance is expected.

\footnotetext{
${ }^{6}$ A lack of suitable instruments for models in which both the linear and squared terms of CVC geographic diversity are included prevented us from estimating full GMM variants of the models.
} 
We furthermore argued that the positive effect of geographic diversity is subject to important boundary conditions - in particular in the context of simultaneous engagement in technology alliances. First, high levels of diversity may diminish the effectiveness of CVC investment portfolios due to increasing managerial complexity, coordination costs, and resource constraints, and these issues are likely to be more pronounced if firms pursue geographic diversity in both technology alliances and CVC investments. Second, if technology alliances and CVC investments target similar locations, this can lead to knowledge redundancy due to the exploration of knowledge in the same innovation systems, reducing the efficiency of the overall knowledge sourcing portfolio. We found broad empirical support for these conjectures when relating technological performance to CVC investment and technology alliance portfolios for a panel of 55 CVC-active firms in a variety of industries.

Our paper makes several contributions to the CVC literature. First, while prior literature has focused on the returns related to the size of knowledge-sourcing portfolios (e.g. Wadhwa and Kotha, 2006; van de Vrande et al., 2011) and technology diversity in CVC portfolios (Yang et al., 2014; Wadhwa et al., 2015; Matusik and Fitza, 2012), our research contributes to the CVC literature by highlighting the role of the geographic diversity of CVC investments. Our analysis goes beyond the general insight that international venturing is positively related to performance (Zahra and Hayton, 2008). We highlight that it is the geographic diversity of international venturing that matters - an important dimension that has received little attention in prior research.

Second, our paper contributes to the literature more generally by demonstrating that the performance effects of CVC investments depend on the broader portfolio of firms' knowledge-sourcing strategies (Dushnitsky and Lavie, 2010). Previous studies have typically juxtaposed various external knowledge-sourcing modes without examining specific complementarities or conflicts between modes (e.g. Keil et al., 2008; Rothaermel and Hess, 2007; van de Vrande et al., 2011; Wadhwa and Kotha, 2006; Wadhwa et al., 2015). In this respect, our study establishes salient interrelationships between CVC investments and technology alliances in firms' efforts to improve innovation performance, suggesting that a lack of coordination at the portfolio level among multiple knowledge sourcing strategies can be detrimental to performance.

More specifically, our findings suggest that redundancy, managerial complexity, and resource constraints occur across the portfolios of technology alliances and CVC investments and not only within the individual portfolios of either of these modes. In this respect, our research provides more detailed evidence for the more general notion put forward in Dushnitsky and Lavie (2010) that potential redundancy and resource constraints influence optimal combinations of CVC investments and technology alliances. Our research 'unpacks' these conflicts by identifying overlaps in the geographic sources of knowledge and of specific technologies as the causes of redundancy, and we identify the combination of sourcing-mode diversity and geographic diversity as the most salient influence on complexity.

We note that our findings on conflicts in portfolios that combine technology alliances with CVC investments should not be interpreted as identifying a general lack of complementarity between alliances and CVC investments. First, technology alliances and CVC investments complement each other if portfolios are structured to avoid redundancy and complexity. Second, it should be emphasized that our analysis focused on a narrow set of alliances characterized by knowledge creation and knowledge sourcing objectives - in line with our research questions and dependent variable. Such technology alliances are most likely to be similar in their objectives to CVC investments-in particular, early-stage CVC investments. While this is instrumental for properly identifying alliance-CVC interactions in knowledge-sourcing, it can be safely assumed that alliances with other objectives (e.g., those focused on marketing and distribution) have a clearer complementary relationship with CVC activities.

The notion of broader objectives of alliances also relates to another feature of our research: we examined the consequences for technological performance of simultaneously pursuing diversified technology-sourcing strategies, but abstained from exploring more complex patterns of intertemporal relationships between such strategies. The relatively short time span for which we gathered our data and the difficulties associated with identifying simultaneous as well as intertemporal interactions between complex portfolios prevented us from pursuing this. Prior studies have for instance suggested that intertemporal stability in strategies may enhance performance (Vermeulen and Barkema, 2002; Shi and Prescott, 2011; Shi et al., 2012; Belderbos et al., 2015a, 2015b). An interesting avenue for future research would be to examine whether a sequential, rather than concurrent, balance in sourcing strategies has positive performance consequences. For instance, CVC investments may be a precursor to alliance strategies (Sykes, 1990; van de Vrande and Vanhaverbeke, 2013), while participation in strategic alliances in turn may make a firm both a more attractive partner for CVC target firms and help identify potential local CVC targets (Dushnitsky and Lavie, 2010).

One of the limitations of our research is that our theorizing focused on a substantive theory of CVC investments (e.g. Burgelman, 2011; Basu et al., 2011). Hence, our aim has been to better understand the consequences of the observed phenomenon of the internationalization of CVC investment portfolios in conjunction with firms' technology alliance activities, but not to develop a general theory of search and organizational learning through CVC investments. Another limitation is our conceptualization of technology alliances and CVC investments as similar instruments of overseas knowledge sourcing-controlling for other potential considerations behind CVC investments. However, CVC investments and technology alliances may have differential advantages in different international settings due to, for example, geographical variations in the availability of venture and alliance partners and firms' ability to attract these partners. Further research may adopt a broader focus and include considerations of when and where one mode of knowledge sourcing may be more efficient than the other. Such endeavors would also take into account other types of heterogeneity in CVC investments related to, for instance, the nature of investor involvement (e.g. Wadhwa and Kotha, 2006), and potential strategic goals related to the leveraging of existing technologies (Yang et al., 2014; Keil, 2004).

Finally, our study could not take into account potential organizational moderators of the performance effects of CVC investments in the context of broader knowledge-sourcing portfolios. Firms may treat CVC investments and alliances as distinct activities (Kale et al., 2002) managed rather independently by different personnel and units. While this may mitigate issues related to managerial complexity, it may also imply that tradeoffs are not easily recognized or acted upon. An unanswered question pertains to the role that 
dedicated organizational units managing CVC investments (e.g. Hill and Birkinshaw, 2015) and technology alliances (e.g. Dyer and Singh, 1998; Kale et al., 2002; Hoang and Rothaermel, 2005; Sarkar et al., 2009; Schilke and Goerzen, 2010) could play in addressing managerial complexities and knowledge redundancies that arise from diversified portfolios of alliances and CVC investments. A CVC unit, owing to its semi-autonomous character, may perhaps be well placed to perform the role of integrating its knowledge-sourcing strategy with the overall knowledge-development strategy of the parent firm. Corporate alliance units, although often falling under the direct responsibility of top management, may perform a similar function in regard to alliances. It will be interesting, therefore, to explore in future work how dedicated alliance and CVC units interact to potentially attenuate the tradeoffs between technology alliances and CVC investments.

\section{Acknowledgements}

The authors wish to thank the editor Suresh Kotha, three anonymous referees, Gino Catani, Thomas Keil, Martin Ganco, Jeff York, and participants at the 2012 SMS conference in Prague and the 2012 Israel Strategy conference in Tel Aviv for their comments on earlier drafts. Nico Rasters, Ibrahim Bolat, and Borut Vovsek provided research assistance. The authors gratefully acknowledge funding by European Union Grant FP7-SSH-2007-1/217296 ("The changing nature of Internationalization of Innovation in Europe: impact on firms and the implications for innovation policy in the Europe").

\section{References}

Ahuja, G., Katila, R., 2001. Technological acquisitions and the innovation performance of acquiring firms: a longitudinal study. Strateg. Manag. J. 22, 197-220. Ahuja, G., Katila, R., 2004. Where do resources come from? The role of situations. Strateg. Manag. J. 25 (8-9), 887-907.

Ahuja, G., Lampert, C.M., 2001. Entrepreneurship in a large corporation: a longitudinal study of how established firms create breakthrough inventions. Strateg. Manag. J. $22,521-543$.

Allen, S.A., Hevert, K.T., 2007. Venture capital investing by information technology companies: did it pay? J. Bus. Ventur. 22 (2), $262-282$.

Almeida, P., Song, J., Grant, R.M., 2002. Are firms superior to alliances and markets? An empirical test of cross-border knowledge building. Organ. Sci. 13 (2), $147-161$.

Anderson, P., 1999. Perspective: complexity theory and organization science. Organ. Sci. 10 (3), $216-232$.

Basberg, B.L., 1987. Patents and the measurement of technological change: a survey of the literature. Res. Policy 16 (2), 131-141.

Basu, S., Phelps, C., Kotha, S., 2011. Towards understanding who makes corporate venture capital investments and why. J. Bus. Ventur. 26 (2), $153-171$.

Belderbos, R.A., Zou, J., 2009. Real options and foreign affiliate divestments: a portfolio perspective. J. Int. Bus. Stud. 40, 600-620.

Belderbos, R., Jacob, J., Lokshin, B., 2011. Geographic diversity and the effects of M \& As and technology alliances on innovative performance. In: Paper Presented at the DIME Conference, UNU-MERIT, Maastricht, April 2011.

Belderbos, R., Carree, M., Fernández Sastre, J., Lokshin, B., 2015a. Inter-temporal patterns of R \& D collaboration and innovative performance. J. Technol. Transfer. 40 (1), 123-137.

Belderbos, R., Lokshin, B., Sadowski, B., 2015b. The returns to foreign R \& D. J. Int. Bus. Stud. 46 (4), $491-504$.

Blundell, R., Griffith, R., van Reenen, J., 1999. Market share, market value and innovation in a panel of British manufacturing firms. Rev. Econ. Stud. 66 (3), 529-554. Burgelman, R.A., 2011. Bridging history and reductionism: a key role for longitudinal qualitative research. J. Int. Bus. Stud. 42 (5), $591-601$.

Cameron, C., Trivedi, P., 1998. Regression Analysis of Count Data. Cambridge University Press.

Certo, J.S., Busenbark, J.R., Woo, H.-S., Semade, M., 2016. Sample selection bias and Heckman models in strategic management research. Strateg. Manag. J. 37 (13), 2639-2657.

Chesbrough, H., 2002. Making sense of corporate venture capital. Harv. Bus. Rev.

Chesbrough, H.W., Tucci, C.L., 2004. Corporate Venture Capital in the Context of Corporate Innovation, Working Paper, Haas School of Business, UC-Berkeley (2004). Chung, W., Yeaple, S., 2008. International knowledge sourcing: evidence from U.S. firms expanding abroad. Strateg. Manag. J. 29 (11), $1207-1224$.

Cohen, W.M., Levinthal, D.A., 1990. Absorptive capacity: a new perspective on learning and innovation. Adm. Sci. Q. 128-152.

Daft, R.L., Lengel, R., 1986. Organizational information requirements, media richness, and structural design. Manag. Sci. 32, 554-571.

Das, T.K., Teng, B., 2000. A resource-based theory of strategic alliances. J. Manag. 26, 31-61.

Davis, J.P., Eisenhardt, K.M., 2011. Rotating leadership and collaborative innovation recombination processes in symbiotic relationships. Adm. Sci. Q. 56 (2), 159-201.

Dess, G.G., Beard, D.W., 1984. Dimensions of organizational task environments. Adm. Sci. Q. 52-73.

Dushnitsky, G., 2006. Corporate venture capital: past evidence and future directions. In: Oxford Handbook of Entrepreneurship, pp. $387-431$.

Dushnitsky, G., 2011. Riding the next wave of corporate venture captial. Bus. Strateg. Rev. 22 (3), 44-49.

Dushnitsky, G., Lavie, D., 2010. How alliance formation shapes corporate venture capital investment in the software industry: a resource-based perspective. Strateg. Entrep. J. 4 (1), 22-48.

Dushnitsky, G., Lenox, M.J., 2005. When do incumbents learn from entrepreneurial ventures? Res. Policy 34 (5), 615-639.

Dushnitsky, G., Lenox, M.J., 2006. When does corporate venture capital investment create firm value? J. Bus. Ventur. 21 (6), $753-772$.

Dyer, J.H., Singh, H., 1998. The relational view: cooperative strategy and sources of interorganizational competitive advantage. Acad. Manag. Rev. 23, 660-679.

Fleming, L., 2001. Recombinant uncertainty in technological search. Manag. Sci. 47 (1), 117-132.

Foss, N.J., Lyngsie, J., Zahra, S.A., 2013. The role of external knowledge sources and organizational design in the process of opportunity exploitation. Strateg. Manag. J. http://dx.doi.org/10.1002/smj.2135.

Furman, J.L., Porter, M.E., Stern, S., 2002. The determinants of national innovative capacity. Res. Policy 31 (6), $899-933$.

Goerzen, A., Beamish, P.W., 2005. The effect of alliance network diversity on multinational enterprise performance. Strateg. Manag. J. $26,333-354$.

Gompers, P., 1995. Optimal investment, monitoring, and the staging of venture capital. J. Financ. 50 (5), $1461-1491$.

Griliches, Z., 1990. Patent statistics as economic indicators: a survey. J. Econ. Lit. 28, 1661-1707.

Gulati, R., 1995. Familiarity breeds trust? The implications of repeated ties on contractual choice in alliances. Acad. Manag. J. 38, 85-112.

Gulati, R., Singh, H., 1998. The architecture of cooperation: managing coordination costs and appropriation concerns in strategic alliances. Adm. Sci. Q. 43 (4), $781-814$.

Haans, R.F.J., Pieters, C., He, Z.-L., 2016. Thinking about U: theorizing and testing U- and inverted U-shaped relationships in strategy research. Strateg. Manag. J. 7, $1177-1195$.

Haas, M., Hansen, M., 2004. When using knowledge can hurt performance: the value of organizational capabilities in a management consulting company. Strateg. Manag. J. 26, 1-24.

Hamel, G., Doz, Y.L., Prahalad, C.K., 1989. Collaborate with your competitors and win. Harv. Bus. Rev. 67 (1), $133-139$.

Henderson, J., Leleux, B., 2002. Corporate venture capital: Effecting resource combinations and transfers. In: Babson Entrepreneurial Review. 31-46 (October).

Hennart, J.F., Reddy, S., 1997. The choice between mergers/acquisitions and joint ventures: the case of Japanese investors in the United States. Strateg. Manag. J. 18, 
$1-12$.

Hill, S.A., Birkinshaw, J., 2015. Ambidexterity and survival in corporate venture units. J. Manag. 40 (7), $1899-1931$.

Hoang, H.T., Rothaermel, F.T., 2005. The effect of general and partner-specific alliance experience on joint R \& D project performance. Acad. Manag. J. 48 (2), $332-345$.

Hoetker, G., Agarwal, R., 2004. Death Hurts, But It Isn't Fatal: The Post-exit Diffusion of Knowledge Created by Innovative Companies. (UIUC working paper). Hoffmann, W.H., 2007. Strategies for managing a portfolio of alliances. Strateg. Manag. J. 28, 827-856.

Hurry, D., Miller, A.T., Bowman, E.H., 1992. Calls on high-technology: Japanese exploration of venture capital investments in the United States. Strateg. Manag. J. 13, 85-101.

Jaffe, A.B., Trajtenberg, M., Henderson, R., 1993. Geographic localization of knowledge spillovers as evidenced by patent citations. Quart. J. Econom. 108, 577-598. Kale, P., Dyer, J., Singh, H., 2002. Alliance capability, stock market response and long-term alliance success: the role of the alliance function. Strateg. Manag. J. 23, 747-767.

Katila, R., Ahuja, G., 2002. Something old, something new: a longitudinal study of search behavior and new product introduction. Acad. Manag. J. 45 (6), $1183-1194$. Keil, T., 2004. Building external corporate venturing capability: initial conditions, learning processes and knowledge management. J. Manag. Stud. 41 (5), 799-825.

Keil, T., Maula, M., Schildt, H., Zahra, S.A., 2008. The effect of governance modes and relatedness of external business development activities on innovative performance. Strateg. Manag. J. 29, 895-907.

Kim, M., 2015. Geographic scope, isolating mechanisms, and value appropriation. Strateg. Manag. J. 37 (4), $623-815$.

Kogut, B., Zander, U., 1992. Knowledge of the firm, combinative capabilities, and the replication of technology. Organ. Sci. 3 (3), $383-397$.

Lahiri, N., 2010. Geographic distribution of R \& D activity: how does it affect innovation quality. Acad. Manag. J. 53 (5), 1194-1200.

Laursen, K., Salter, A., 2006. Open for innovation: the role of openness in explaining innovation performance among UK manufacturing firms. Strateg. Manag. J. 27 (2), 131-150.

Lavie, D., Miller, S.R., 2008. Alliance portfolio internationalization and firm performance. Organ. Sci. 19 (4), $623-646$.

Lavie, D., Kang, J., Rosenkopf, L., 2011. Balance within and across domains: the performance implications of exploration and exploitation in alliances. Organ. Sci. 22 (6), 1517-1538.

Leiponen, A., Helfat, E., 2011. Location, decentralization and knowledge sources for innovation. Organ. Sci. 22 (3), 641-658.

Leten, B., Belderbos, R., Van Looy, B., 2016. Entry and performance in new technology domains. J. Manag. Stud. 53 (8), $1257-1291$.

Levinthal, D.A., March, J.G., 1993. The myopia of learning. Strateg. Manag. J. 14, 95-112 (Winter Special Issue).

MacMillan, I., Roberts, E., Livada, V., Wang, A., 2008. Corporate venture capital (CVC): seeking innovation and strategic growth. In: National Institute of Standards and Technology-US Department of Commerce, pp. 08-916.

Matusik, S.F., Fitza, M.A., 2012. Diversification in the venture capital industry: leveraging knowledge under uncertainty. Strateg. Manag. J. 33, 407-426.

Mitchell, W., 1989. Whether and when: probability and timing of incumbents entry into emerging industrial subfields. Adm. Sci. Q. 34 (2), 208-230.

Narayanan, V.K., Yang, Y., Zahra, S.A., 2009. Corporate venturing and value creation: a review and proposed framework. Res. Policy 38 (1), $58-76$.

North, D., 1990. Institutions, Institutional Change and Economic Performance. Cambridge University Press, Cambridge.

Novick, L.R., 1988. Analogical transfer, problem similarity, and expertise. J. Exp. Psychol. Learn. Mem. Cogn. 14 (3), 510.

Parkhe, A., 1993. Partner nationality and the structure-performance relationship in strategic alliances. Organ. Sci. 4 (2), $301-324$.

Phene, A., Fladmoe-Lindquist, K., Marsh, L., 2006. Breakthrough innovations in the U.S. biotechnology industry: the effects of technological space and geographic origin. Strateg. Manag. J. 27, 369-388.

Porter, M.E., 1990. The Competitive Advantage of Nations. Free Press, New York.

Rosenkopf, L., Almeida, P., 2003. Overcoming local search through alliances and mobility. Manag. Sci. 49 (6), $751-766$.

Rosenkopf, L., Nerkar, A., 2001. Beyond local search: boundary-spanning, exploration, and impact in the optical disk industry. Strateg. Manag. J. 22 (4), 287-306.

Rothaermel, F.T., Hess, A.M., 2007. Building dynamic capabilities: innovation driven by individual-, firm-, and network-level effects. Organ. Sci. 18 (6), 898-921.

Sampson, R.C., 2007. R\&D alliances and firm performance: the impact of technological diversity and alliance organization on innovation. Acad. Manag. J. 50 (2), 364-386.

Sarkar, M.B., Aulakh, P.S., Madhok, A., 2009. Process capabilities and value generation in alliance portfolios. Organ. Sci. 20 (3), $583-600$.

Saxenian, A., 1994. Regional Advantage. Harvard University Press, Cambridge, MA.

Schilke, O., Goerzen, A., 2010. Alliance management capability: an investigation of the construct and its measurement. J. Manag. 36, 1192-1219.

Schilling, M.A., 2009. Understanding the alliance data. Strateg. Manag. J. 30 (3), 233-260.

Schmoch, U., 2008. Concept of a technology classification for country comparisons. In: Final Report to the World Intellectual Property Office (WIPO). Fraunhofer ISI, Karslruhe.

Schmookler, J., 1966. Invention and Economic Growth. Harvard University Press, Cambridge.

Shi, W., Prescott, J.E., 2011. Sequence patterns of firms' acquisition and alliance behavior and their performance implications. J. Manag. Stud. 48, 1044-1070.

Shi, W., Sun, J., Prescott, J.E., 2012. A temporal perspective of merger and acquisition and strategic alliance initiatives: review and future direction. J. Manag. 38 (1), 164-209.

Song, J., Almeida, P., Wu, G., 2003. Learning-by-hiring: when is mobility more likely to facilitate interfirm knowledge transfer? Manag. Sci. 49 (4), 351-365.

Stettner, U., Lavie, D., 2014. Ambidexterity under scrutiny: exploration and exploitation via internal organization, alliances, and acquisitions. Strateg. Manag. J. 35 (13), 1903-1929.

Sykes, H., 1990. Corporate venture capital: strategies for success. J. Bus. Ventur. 5 (1), 37-47.

van de Vrande, V., 2013. Balancing your technology-sourcing portfolio: how sourcing mode diversity enhances innovative performance. Strateg. Manag. J. 34 (5), 610-621.

van de Vrande, V., Vanhaverbeke, W., 2013. How prior corporate venture capital investments shape technological alliances: a real options approach. Entrep. Theory Pract. 37 (5), 1019-1043.

van de Vrande, V., Vanhaverbeke, W., Duysters, G., 2011. Technology in-sourcing and the creation of pioneering technologies. J. Prod. Innov. Manag. 28, 974-987.

Vassolo, R.S., Anand, J., Folta, T.B., 2004. Non-additivity in portfolios of exploration activities: a real options-based analysis of equity alliances in biotechnology. Strateg. Manag. J. 25 (11), 1045-1061.

Vermeulen, F., Barkema, H., 2002. Pace, rhythm, and scope: process dependence in building a profitable multinational corporation. Strateg. Manag. J. 23 (7), $637-653$.

Verspagen, B., Schoenmakers, W., 2004. The spatial dimension of patenting by multinational firms in Europe. J. Econ. Geogr. 4 (1), $23-42$.

Wadhwa, A., Kotha, S., 2006. Knowledge creation through external venturing: evidence from the telecommunications equipment manufacturing industry. Acad. Manag. J. 49 (4), 1-17.

Wadhwa, A., Phelps, C., Kotha, S., 2010. Creating exploratory innovations by learning from entrepreneurial ventures. In: New Frontiers in Entrepreneurship. Springer New York, pp. 147-173.

Wadhwa, A., Phelps, C., Kotha, S., 2015. Corporate venture capital portfolios and firm innovation. J. Bus. Ventur. 13 (1), $95-112$.

Winter, S., 1987. Knowledge and competence as strategic assets. In: Teece, David J. (Ed.), The Competitive Challenge-Strategies for Industrial Innovation and Renewal. Ballinger, Cambridge, MA, pp. 159-184.

Yang, Y., Narayanan, V.K., De Carolis, D.M., 2014. The relationship between portfolio diversification and firm value: the evidence from corporate venture capital activity. Strateg. Manag. J. 35, 1993-2001.

Zahra, S.A., Hayton, J.C., 2008. The effect of international venturing on firm performance: the moderating influence of absorptive capacity. J. Bus. Ventur. 23 (2), $195-220$.

Zhang, Y., Li, H., Zhou, L., 2010. FDI spillovers in an emerging market: the role of foreign firms' country origin diversity and domestic firms' absorptive capacity. Strateg. Manag. J. 31, 969-989.

Zollo, M., Reuer, J.J., Singh, H., 2002. Interorganizational routines and performance in strategic alliances. Organ. Sci. 13, 701-713. 